\section{Shybetskyi V., Kostyk 5.}

\title{
ANALYSIS OF THE SPECIAL FEATURES OF HYDRODYNAMICS IN THE BOUNDARY LAYER OF THE NOZZLE OF THE DEVELOPED SURFACE
}

Об’єктом дослідженням є гідродинаміка пограничного шару насадкового елементу запропонованої конструкції. В ході проведення дослідження були використані методи комп'ютерного моделювання в середовищі ANSYS, зокрема блок CFX, що включає сукупність фізичних, математичних $і$ чисельних методів, призначених для обчислення характеристик потокових прочесів. Проведено аналіз впливу швидкості руху рідини в насадковому біореакторі на величину гідравлічного опору для наступних величин швидкостей руху рідини: 0,1 м/с; $1 \mathrm{~m} / \mathrm{c} ; 2 \mathrm{~m} / \mathrm{c}$. Отримані дані майже повторюють значення експериментальних досліджень, що підтверджує правильність побудови комп'ютерної моделі. Проведено моделювання гідродинаміки одиночної насадки запропонованої конструкції при поздовжньому та поперечному обтіканні потоком рідини. Зміни гідравлічного опору при поперечному обтіканні насадки незначні, максимальне значення лежить в межах 101,3 кПа, при повздовжньму омиванні значення перепаду тиску лежить в межах від 98,96 до 102,7 кПа. Отримано епюри розподілення полів та векторів швидкостей в пограничному шарі насадки. При поперечному омиванні насадки величина швидкостей знаходиться в межах від 0 до 1,511 м/с, при повздовжньому омиванні лежить в межах від 0 до 1,968 м/с. Встановлено розподіл величини швидкості зсуву в приграничному шарі, при поперечному омиванні насадки величина швидкості зсуву потоку лежчть в межах від 3,1 до 4,27.103 $\mathrm{c}^{-1}$, при повздовжньому обтіканні насадки цей показник становить від 5,6

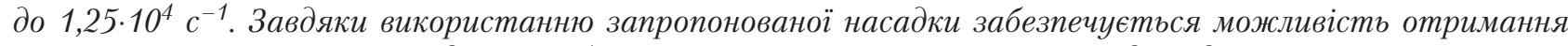
великих питомих поверхонь для іммобілізації мікроорганізмів, за умови відповідності критичних параметрів прочесу культивування допустимим граничним відхиленням. У порівнянні з методами визначення оптимальних параметрів експериментальним шляхом запропонована комп'ютерна модель забезпечує такі переваги: суттєве зменшення матеріальних витрат на впровадження нової конструкиї насадки та швидку оптимізацію параметрів проведення процесу за зміни вихідних даних.

Ключові слова: насадковий біореактор, напруження зсуву, комп'ютерне моделювання в середовищі ANSYS, гідравлічний опір, швидкість зсуву потоку.

\section{Introduction}

The use of developed heat and mass transfer surfaces, today, is widely used in various industries [1, 2]. In biotechnology quite often use packed bed mass-exchange apparatus, which are columns filled with nozzles of various shapes, that is, bodies which geometric shape is substantially developed in comparison with their volume [3]. The contact of the gas (fluid) with the fluid occurs on the wetted surface of the nozzle, on which the absorbent fluid flows. Fluid flow along a nozzle is usually film-like, therefore they are often referred to as film [4]. Creating new designs of nozzles with a more developed specific surface area is an important task. However, when designing, it is necessary to take into account some limiting parameters, such as: hydrodynamics in the boundary layer of the nozzle, features of manufacturing the nozzle and the use of inert materials [5]. Since the movement of fluid near the nozzle surface carries a purely laminar regime, it significantly affects heat and mass transfer, therefore the object of research is the hydrodynamics of the boundary layer of the nozzle element of the proposed design. And the aim of research is simulation of the hydrodynamics of the nozzle of the developed surface of the proposed design in the ANSYS environment. The establishment of hydrodynamic features near the nozzle of the proposed design will allow to establish the optimal parameters and evaluate the possibility of using the nozzles of the proposed design in packed bed mass transfer devices.

\section{Methods of research}

2.1. Modeling hydrodynamics of a porous layer in a closed volume in the ANSYS environment. For computer simulation of the flow of fluid through a porous nozzle, the ANSYS environment, namely the CFX module, is used. For the adequacy of the model to real processes, it is necessary to form conditions of unambiguity.

Geometric conditions. Before modeling the process, let's construct the geometry of the volume of the inner cavity of the bioreactor in the SolidWorks environment, in which the fluid is in the process of cultivation. Let's divide this volume into three domains (Fig. 1). The height of the nozzle placement zone is $80 \mathrm{~mm}$, the diameter of the internal cavity is $95 \mathrm{~mm}$, the total height of the volume is $120 \mathrm{~mm}$.

Physical conditions. Before setting physical conditions, it is necessary to split the domains into finite elements. To do this, using Mesh, create a mesh using the default settings. The mesh formation is performed using the form of triangular pyramids, since the use of this type of split 
even increases the required design power, however, it gives an opportunity to evaluate the hydrodynamic features at a deeper level. The minimum element size is $1.07 \cdot 10^{-5} \mathrm{~m}$ and the maximum surface size is $1.07 \cdot 10^{-3} \mathrm{~m}$. Relevance Center: Fine and Smoothing: High parameters are selected to create the mesh. Next, for each of the domains, let's define the physical conditions. Environment, which is washed the nozzles, is a fluid with thermophysical parameters of water, a nozzle - aluminum elements with a porosity of 0.6 .

Boundary conditions. On the upper end of the volume, let's set the velocity of the fluid $w$, and the lower yield of the fluid without the additional hydraulic resistance $P$. The outer surfaces of the cylinder are defined as an adiabatic wall without slipping the fluid.

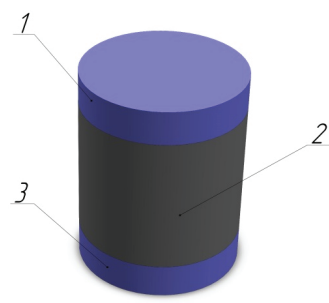

Fig. 1. The geometry of the simulated volume:

1,3 - the domain in which there can only be fluid; 2 - the domain in which the nozzle is located

2.2. Simulation of hydrodynamics of the boundary layer of the nozzle of the proposed design in the ANSYS environment. Using a similar technique, let's simulate the hydrodynamics of the nozzle of the proposed design. To do this, let's create its geometry in the SolidWorks environment. It represents a continuous volume in which there can be a fluid, from which the volume of the nozzle is cut to reduce the required calculated computer power (Fig. 2).

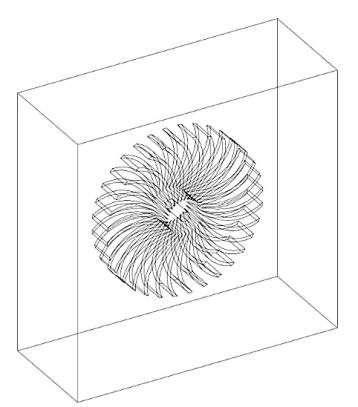

Fig. 2. Model geometry

Next, the volume is divided into a mesh by the finite element method and set the initial, physical and boundary conditions. Physical conditions: fluid - water. Boundary conditions: velocity at the entrance to the volume; outlet pressure; all other surfaces are symmetrical, that is, those that do not affect the movement of the fluid. Initial conditions: fluid volume is fixed at the initial moment of time.

\section{Research results and discussion}

3.1. Hydrodynamics of a porous layer in a closed volume in the ANSYS environment. According to the calculation results, the gradient of pressure distribution in the packing is obtained (Fig. 3). From the obtained results it can be seen that the pressure is redistributed almost linearly, although there are disturbances in the near-wall area of the nozzle.

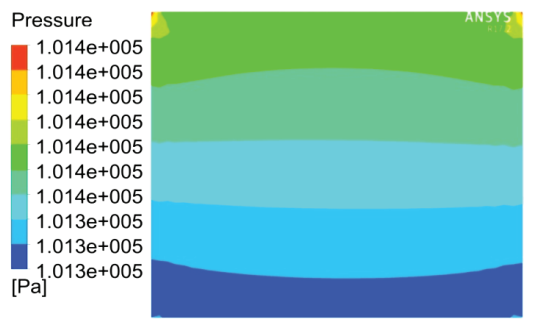

Fig. 3. Gradient pressure distribution

When analyzing the effect of fluid velocity on the value of hydraulic resistance, a study is conducted for the following movements of $0.1 \mathrm{~m} / \mathrm{s} ; 1 \mathrm{~m} / \mathrm{s} ; 2 \mathrm{~m} / \mathrm{s}$. So, at a velocity of $0.1 \mathrm{~m} / \mathrm{s}$, the value of the hydraulic resistance of the nozzle layer is $2 \mathrm{~Pa}$, at $1 \mathrm{~m} / \mathrm{s}-35 \mathrm{~Pa}$, and at $2 \mathrm{~m} / \mathrm{s}-105 \mathrm{~Pa}$. The obtained values are almost the same as those obtained in experimental studies [6]. This makes it possible to assert that the model constructed rather adequately assesses the hydrodynamic situation when a fluid flows through the nozzle and can be used to estimate the hydraulic resistance when scaling processes and using new packing elements.

3.2. Hydrodynamics of a single nozzle in the ANSYS environment. During transverse washing of the nozzle, the value of hydraulic resistance does not actually change and lies within the limits of $101.3 \mathrm{kPa}$, while for longitudinal washing the value of the pressure drop changes significantly and ranges from $98.96 \mathrm{kPa}$ to $102.7 \mathrm{kPa}$ (Fig. 4). This fact suggests that the location of the nozzle elements in the fluid flow should be predominantly transverse in nature, which will help reduce the hydraulic resistance of the nozzle layer.

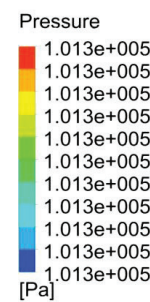

$1.013 \mathrm{e}+005$

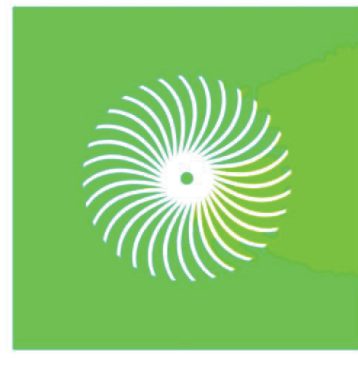

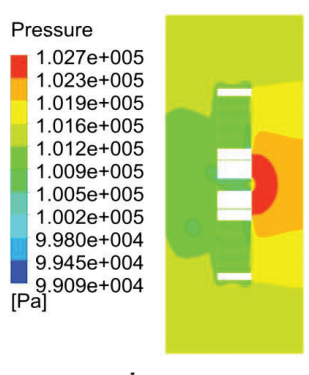

Fig. 4. Fields of pressure distribution near the nozzle: $a$ - for transverse washing of the nozzle; $b$ - for longitudinal washing of the nozzle

Analyzing the results obtained for the fields and velocity vectors in the nozzle boundary layer, the following features are established (Fig. 5). When transversal washing of the nozzle, the magnitude of the velocity vectors is in the range from 0 to $1.511 \mathrm{~m} / \mathrm{s}$, while in the case of longitudinal washing, the range of values of the velocity changes more widely and ranges from 0 to $1.968 \mathrm{~m} / \mathrm{s}$.

It should also be noted that the size of the contour, in which the flow rate of the fluid is close to $0 \mathrm{~m} / \mathrm{s}$ is several dozen times greater in the case of transverse flow 
of the nozzle, which indicates a high probability of the occurrence of so-called stagnation zones, in which it is impossible to create an intense heat and mass transfer (Fig. 5). This fact suggests that the location of the nozzle elements in the fluid flow, from the point of view of preventing the occurrence of stagnation zones, should be predominantly longitudinal in nature, which will increase the efficiency of heat and mass transfer coefficients [7]. One of the most important characteristics when using nozzles in mass-mass apparatus, especially during the cultivation of surface-dependent cells, are the so-called shear stresses, the value of which is proportional to the product of the shear rate of flow by the dynamic viscosity coefficient (Fig. 6).
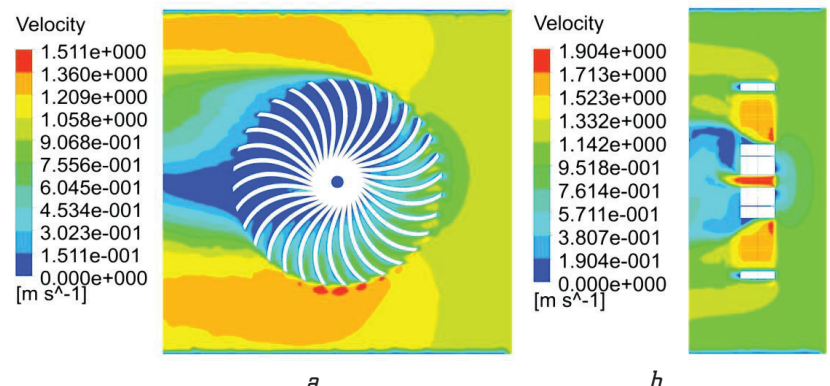

Fig. 5. Fields of velocity in the boundary layer of the nozzle fluid: $a$ - for transverse washing of the nozzle; $b$ - for longitudinal washing of the nozzle

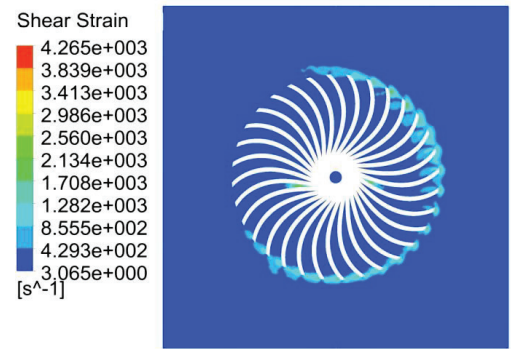

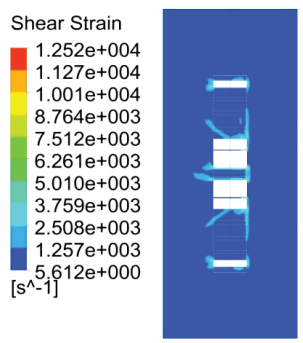

$b$
Fig. 6. The rate of flow shear in the boundary layer of the nozzle fluid: $a$ - for the transverse washing of the nozzle; $b-$ for longitudinal washing of the nozzle

Moving in channels of complex shape, at significant velocities and low viscosities, the fluid can create highgradient zones with significant shear stresses that can damage mammalian cells during cultivation $[8,9]$. Therefore, when designing packed bed mass exchangers (bioreactors), it is necessary to control the flow shear rate, which according to the literature [10] for mammalian cells should not exceed $10^{4} \mathrm{~s}^{-1}$. Based on this, analysis of the shear stress pattern shows that for transverse washing of the nozzle, the magnitude of the flow shear rate ranges from 3.1 to $4.27 \cdot 10^{3} \mathrm{~s}^{-1}$, while for the longitudinal flow around the nozzle, this figure ranges from 5.6 to $1.25 \cdot 10^{4} \mathrm{~s}^{-1}$ (Fig. 6). Considering the minimum volume of zones with values of flow shear rates of more than $10^{4} \mathrm{~s}^{-1}$, it can be argued that the flow does not create a particular effect on the yield of viable cells. However, it should be noted that a further increase in the flow rate at the inlet is not rational from the point of view of the growth of the shear rate of the flow and, accordingly, the hydraulic resistance created by the nozzle layer [10].

\section{Conclusions}

The hydrodynamics of a porous layer of nozzles in a closed volume is simulated and the hydrodynamics of a separate nozzle is simulated; it is washed by the fluid flow in the longitudinal and transverse directions. It is established that the location of the nozzles should be predominantly longitudinal in nature, in order to increase the efficiency of heat and mass transfer coefficients. But, on the other hand, to reduce the hydraulic resistance of the nozzle layer, the location of the nozzle elements in the fluid flow should be predominantly transverse in nature. Therefore, in each particular case, it is necessary to choose which of the parameters is more substantial and to optimize the process taking into account the set task.

\section{References}

1. Zhang C., Li Y. Thermodynamic analysis on theoretical models of cycle combined heat exchange process: The reversible heat exchange process // Energy. 2017. Vol. 124. P. 565-578. doi: http://doi.org/10.1016/j.energy.2017.02.103

2. Osoblyvosti teploviddachi pry vymushenii konvektsii v rotornodyskovomu plivkovomu vyparnomu aparati / Obodovych O. M. Ruzhynska L. I., Kostyk S. I., Bulakh N. M. // Promishlennaia teplotekhnyka. 2016. Issue 6 (37). P. 22-28.

3. Experimental investigation of convective heat transfer from sewage in heat exchange pipes and the construction of a fouling resistance-based mathematical model / Song J., Liu Z., Ma Z., Zhang J. // Energy and Buildings. 2017. Vol. 150. P. 412-420. doi: http://doi.org/10.1016/j.enbuild.2017.06.025

4. Heat Exchange Numerical Modeling of a Submarine Pipeline for Crude Oil Transport / Lanzafame R., Mauro S., Messina M., Brusca S. // Energy Procedia. 2017. Vol. 126. P. 18-25. doi: http:// doi.org/10.1016/j.egypro.2017.08.048

5. Influence of various aspects of low Reynolds number $k-\varepsilon$ turbulence models on predicting in-tube buoyancy affected heat transfer to supercritical pressure fluids / Zhao C.-R., Zhang Z., Jiang P.-X., Bo H.-L. // Nuclear Engineering and Design. 2017. Vol. 313. P. 401-413. doi: http://doi.org/10.1016/ j.nucengdes.2016.12.033

6. Jafari M., Farhadi M., Sedighi K. Thermal performance enhancement in a heat exchanging tube via a four-lobe swirl generator: An experimental and numerical approach // Applied Thermal Engineering. 2017. Vol. 124. P. 883-896. doi: http://doi.org/ 10.1016/j.applthermaleng.2017.06.095

7. Shybetskiy V., Semeniuk S., Kostyk S. Design of consrtuction and hydrodynamic modeling in a roller bioreactor with surface cultivation of cell cultures // ScienceRise. 2017. Vol. 7, Issue 36. P. 53-59. doi: http://doi.org/10.15587/2313-8416.2017.107176

8. Hydrodynamics of fermenter with multi-shaft stirrer / Zakomornyi D. M., Kutovyi M. H., Kostyk S. I., Povodzynskyi V. M., Shybetskyi V. Yu. // ScienceRise. 2016. Vol. 5, Issue 2 (22) P. 65-70. doi: http://doi.org/10.15587/2313-8416.2016.69451

9. Mathematical simulation of hydrodynamics of the mixing device with magnetic drive / Kostyk S. I., Ruzhynska L. I., Shybetskyi V. Yu., Revtov O. O. // ScienceRise. 2016. Vol. 4, Issue 2 (21). P. 27-31. doi: http://doi.org/10.15587/23138416.2016 .67275

10. Cell Membranes Resist Flow / Shi Z., Graber Z. T., Baumgart T., Stone H. A., Cohen A. E. // Cell. 2018. Vol. 175, Issue 7. P. 1769. doi: http://doi.org/10.1016/j.cell.2018.09.054

Shybetskyy Vladislav, PhD, Associate Professor, Department of Biotechnology and Engineering, National Technical University of Ukraine «Igor Sikorsky Kyiv Polytechnic Institute», Ukraine, ORCID: https://orcid.org/ 0000-0001-5482-0838, e-mail: v.shybetsky@gmail.com

Kostyk Serhii, PhD, Senior Lecturer, Department of Biotechnology and Engineering, National Technical University of Ukraine «Igor Sikorsky Kyiv Polytechnic Institute», Ukraine, ORCID: http://orcid.org/ 0000-0002-2817-7233,e-mail: kostyksergey@ukr.net 